\title{
The role of hepcidin in the pathogenetic mechanisms of anemia of inflammation development in young children with acute inflammatory bacterial diseases of the respiratory system
}

\author{
H. O. Lezhenko ${ }^{D} \star A, E, F$, A. O. Pogribna ${ }^{\mathrm{B}-\mathrm{D}}$
}

Zaporizhzhia State Medical University, Ukraine

A - research concept and design; B - collection and/or assembly of data; C - data analysis and interpretation; D - writing the article;

$\mathrm{E}$ - critical revision of the article; $\mathrm{F}$ - final approval of the article

Aim. To determine the pathogenetic role of hepcidin in the development of anemia of inflammation in young children.

Materials and methods. The content of hepcidin, ferritin and erythropoietin was studied in young children. The serum total iron-binding capacity, the coefficient of saturation of iron in transferring was determined. The main group consisted of children with acute inflammatory bacterial diseases of the respiratory system: the first subgroup included children with anemia of inflammation, the second group - without anemia. The comparison group included children with iron deficiency anemia without inflammatory manifestations. The control group consisted of conditionally healthy children. The studied groups were age- and sex-representative.

Results. Patients with acute bacterial diseases of respiratory tract who developed anemia of inflammation had an elevated level of hepcidin, doubling the control group indicator $(2.09(1.81 ; 2.24) \mathrm{ng} / \mathrm{ml}$ and $1.07(0.98 ; 1.17) \mathrm{ng} / \mathrm{ml}$, respectively, $\mathrm{P}<0.05)$. Its increase did not depend on the etiological factor of the disease; however, it increased with the disease severity. Low iron content was found in the first subgroup compared with other groups $(P<0.05)$, and in the second subgroup, there was an increasing trend in its content $(P>0.05)$. A high level of ferritin was detected in both subgroups, the concentration of which was 2 times higher than in the control group $(P<0.05)$. A close direct correlation was established between the serum contents of hepcidin and ferritin in the studied groups of children $(r=+0.93, P<0.01)$. The coefficient of saturation of iron in transferring was lower in the main group than in the comparison and control groups $(P<0.05)$. The level of serum total iron-binding capacity was statistically significantly decreased in the first subgroup $(P<0.05)$, and significantly increased in the second subgroup $(P<0.05)$, while there was only its downward trend $(P>0.05)$ in the comparison group. An increase in the content of erythropoietin was observed only in the group of children who were diagnosed with iron deficiency anemia. Its level was statistically significantly higher than the indicators of both subgroups of the main and control groups $(P<0.01)$.

Conclusions. Hepcidin plays a significant pathogenetic role in the development of anemia of inflammation in young children due to the regulatory effect on iron deposition. The increase in its level in response to the development of a bacterial inflammatory process of the respiratory system in young children did not depend on the etiological factor of the disease.

\section{Роль гепсидину в патогенетичних механізмах розвитку анемії запалення в дітей раннього віку, які мають гострі запальні бактеріальні захворювання органів дихання}

\section{Г. О. Леженко, А. О. Погрібна}

Мета роботи - вивчити патогенетичну роль гепсидину в розвитку анемії запалення в дітей раннього віку.

Матеріали та методи. Вивчили вміст гепсидину, феритину та еритропоетину в дітей раннього віку. Визначили загальну залізозв'язувальну здатність сироватки крові, коефіцієнт насиченості трансферину залізом. Основну групу утворили діти з гострими запальними бактеріальними захворюваннями органів дихання: першу підгрупу - діти 3 анемією запалення, другу - без анемії. У групу порівняння ввійшли діти з залізодефіцитною анемією без проявів запалення, в контрольну умовно здорові діти. Групи спостереження репрезентативні за віком і статтю хворих.

Результати. У дітей, які мають гострі бактеріальні захворювання органів дихання і в яких розвинулася анемія запалення, визначили підвищений рівень гепсидину, що був удвічі більшим за показник групи контролю $(2,09(1,81 ; 2,24)$ нг/мл і 1,07 $(0,98 ; 1,17)$ нг/мл відповідно, $p<0,05)$. Йго наростання не залежало від етіологічного фрактора захворювання, однак збільшувалося з ускладненням перебігу захворювання. Низький вміст заліза порівняно з іншими групами встановили в першій підгрупі $(p<0,05)$, у другій підгрупі визначили тенденцію до його підвищення ( $p>0,05)$. Високий рівень феритину виявили в обох підгрупах, його концентрація була вдвічі більшою, ніж у групі контролю $(p<0,05)$. Встановили тісний прямий зв'язок між вмістом гепсидину та фреритину в сироватці крові дітей із груп дослідження ( $r=+0,93, p<0,01)$. Коесріцієнт насичення трансфрерину залізом в основній групі був нижчим, ніж у групах порівняння та контролю $(p<0,05)$. Зниження рівня загальної залізозв'язувальної здатності сироватки крові було статистично значущим в першій підгрупі $(p<0,05)$, вірогідне підвищення цього показника визначили в підгрупі $2(p<0,05)$; у групі порівняння виявили тільки тенденцію до її зниження $(p>0,05)$. Підвищення рівня еритропоетину спостерігали тільки у групі дітей, в яких діагностована залізодесріцитна анемія. Його рівень статистично значущо перевищував показники основної та контрольної груп $(p<0,01)$.

Висновки. Гепсидин відіграє важливу патогенетичну роль у розвитку анемії запалення в дітей раннього віку внаслідок регулювального впливу на процес депонування заліза. Підвищення його рівня у відповідь на розвиток бактеріального запального процесу в органах дихання в дітей раннього віку не залежало від етіологічного фактора захворювання.
Key words: anemia of inflammation, hepcidin, preschoolchildren.

\section{Zaporozhye} medical journal 2020; 22 (4), 473-478

*E-mail: genalezh@gmail.com

Кнючові слова: анемія запалення, гепциАин, Аіти раннього віку.

Запорізький медичний журнал. 2020. T. 22, № 4(121) C. $473-478$ 
Ключевые слова: анемия воспаления, гепсиАин, Аети раннего возраста.

Запорожский медицинский журнал 2020. T. 22, № 4(121) C. $473-478$

\section{Роль гепсидина в патогенетических механизмах развития анемии воспаления у детей раннего возраста, больных острыми воспалительными бактериальными заболеваниями органов дыхания}

\section{Г. А. Аеженко, А. А. Погребная}

Цель работы - изучить патогенетическую роль гепсидина в развитии анемии воспаления у детей раннего возраста.

Материалы и методы. Изучили содержание гепсидина, ферритина и эритропоэтина у детей раннего возраста. Определили общую железосвязывающую способность сыворотки крови, коэффрициент насыщенности трансфреррина железом. Основную группу составили дети с острыми воспалительными бактериальными заболеваниями органов дыхания: в первую подгруппу включены дети с анемией воспаления, во вторую - без анемии. В группу сравнения вошли дети с железодефицитной анемией без воспалительных проявлений, в контрольную - условно здоровые дети. Группы наблюдения репрезентативны по возрасту и полу больных.

Результаты. У детей, больных острыми бактериальными заболеваниями органов дыхания, у которых развилась анемия воспаления, отмечен повышенный уровень гепсидина, который превышал показатели группы контроля в 2 раза $(2,09$ $(1,81 ; 2,24)$ нг/мл и $1,07(0,98 ; 1,17)$ нг/мл соответственно, $p<0,05)$. Его нарастание не зависело от этиологического фактора заболевания, однако увеличивалось при повышении тяжести течения заболевания. Низкое содержание железа в первой подгруппе установлено по сравнению с другими группами $(p<0,05)$, во второй подгруппе отмечена тенденция к его повышению ( $p>0,05)$. Отмечен высокий уровень ферритина в обеих подгруппах, его концентрация была в 2 раза выше, чем в группе контроля $(p<0,05)$. Установлена тесная прямая связь между содержанием гепсидина и ферритина в сыворотке крови детей из групп исследования ( $r=+0,93, p<0,01)$. Коэфффициент насыщения трансферрина железом в основной группе ниже, чем в группах сравнения и контроля $(p<0,05)$. Статистически значимое снижение уровня общей железосвязывающей способности отмечено в первой подгруппе ( $p<0,05)$, а ее достоверное повышение - в подгруппе 2 $(p<0,05)$; в группе сравнения установлена лишь тенденция к ее снижению $(p>0,05)$. Повышение уровня эритропоэтина наблюдали лишь в группе детей, у которых диагностирована железодефицитная анемия. Его уровень статистически значимо превышал показатель основной и контрольной групп ( $p<0,01)$.

Выводы. Гепсидин играет значимую патогенетическую роль в развитии анемии воспаления у детей раннего возраста за счет регулирующего влияния на процесс депонирования железа. Нарастание его уровня в ответ на развитие бактериального воспалительного процесса в органах дыхания у детей раннего возраста не зависело от этиологического фактора заболевания.

The problem of infectious and inflammatory diseases remains one of the most actual in modern pediatrics, due to the high frequency with which this pathology occurs in young children [1]. Continuous improvement in the methods of inflammatory diseases treatment necessitates an in-depth study on various forms of this pathology pathogenesis in order to provide adequate mechanisms of anti-infection protection in patients [2].

Anemia of inflammation (Al) is considered the second most common anemia in the world (after iron-deficiency anemia (IDA)). According to experts, up to $40 \%$ of all anemias can be considered as Al or combined anemia with a significant role of Al. These data indicate that the spectrum of diseases in which inflammation contributes to the development of anemia has expanded in recent years [2]. Despite its prevalence, the pathogenesis of Al has not been fully studied, but scientists suggest that Al can be regarded as a marker of the severity and progression of the disease [3].

The leading mechanism for the development of $\mathrm{Al}$ is the limitation of iron availability for pathogenic bacteria and macroorganisms in general [4]. In response to inhibition of iron uptake by microorganisms, the growth of a wide range of pathogens is suppressed, and sensitivity to the elimination mechanisms of antibacterial agents action is increased [5]. In this regard, indicators that allow predicting the development of $\mathrm{Al}$ in the body deserve attention.

A discovery of hepcidin at the turn of the $20^{\text {th }}-21^{\text {st }}$ centuries added considerably to the existing concept of inflammation and mechanisms of an organism's resistance in response to infection. It plays a polymodal role in iron metabolism. Hepcidin internalizes and degrades ferroportin, a carrier of iron from enterocytes, macrophages, hepatocytes, and placental cells into blood plasma [5]. Disruption of erythropoiesis leads to a suppression of the iron transfer into blood plasma, which is accompanied by a decrease in the degree of transferrin saturation - the plasma iron transporter - and insufficient supply of iron for hemoglobin synthesis in maturing erythroblasts, thus realizing a protective function in reply to the mechanisms of bacterial activity responsible for iron absorption [6]. The above pathogenetic links initiate AI manifestation.

\section{Aim}

To determine the pathogenetic role of hepcidin in the development of $\mathrm{Al}$ in young children.

\section{Materials and methods}

A total of 80 children aged between 1 month and 3 years (with an average age of $1.2 \pm 0.4$ years) were examined. The main group consisted of 40 children with acute bacterial diseases of the respiratory tract. In the main group, bronchitis was diagnosed in 32 (79\%) children, pneumonia - in $8(21 \%)$ children. Among pathogens, Haemophillus influenzae prevailed in 19 (46.6\%) children, Streptococcus pneumoniae - in 12 (30\%) children, Klebsiella pneumoniae - in 4 (10\%). Other pathogens were identified in solitary instances. Given the hematological picture, the main group was divided into two subgroups. The first subgroup included 20 children with $\mathrm{Al}$, which was determined $4-5$ days after the disease onset. The second subgroup consisted of 20 children without anemia. The comparison group was 
Table 1. Some indicators of iron metabolism in the examined children (Me (Q25-Q75))

\begin{tabular}{|c|c|c|c|c|}
\hline \multirow[t]{2}{*}{ Indicators, units } & \multicolumn{2}{|l|}{ The main group, $n=40$} & \multirow[t]{2}{*}{ Comparison group, $\mathrm{n}=\mathbf{2 0}$} & \multirow[t]{2}{*}{ Control group, $n=20$} \\
\hline & Subgroup $1, \mathrm{n}=\mathbf{2 0}$ & Subgroup 2, n = 20 & & \\
\hline Hemoglobin, g/l & $100(97 ; 107)^{*}$ & *129 (119.0; 136.5) & $101(95 ; 106)$ & $125(119 ; 132)$ \\
\hline Serum iron, $\mathrm{mmol} / \mathrm{l}$ & *8.78* $(6.82 ; 15.30)$ & ${ }^{*} 9.85^{*}(7.55 ; 12.50)$ & $13.10(9.74 ; 17.22)$ & $13.88(12.74 ; 16.52)$ \\
\hline Total iron-binding capacity, mmol/l & $41.7^{*}(38.9 ; 49.0)$ & $* 51.46 *(49.30 ; 53.10)$ & $43.8(37.35 ; 48.05)$ & $46.80(41.02 ; 52.25)$ \\
\hline Coefficient of saturation of iron in transferrin, $\%$ & *21.01* $(17.53 ; 31.22)$ & *19.14* $(15.63 ; 23.54)$ & $29.91(26.08 ; 35.84)$ & $29.65(31.05 ; 31.61)$ \\
\hline Hepcidin, ng/ml & $2.09^{*}(1.81 ; 2.24)$ & $1.89^{*}(1.48 ; 2.28)$ & $1.91^{*}(1.33 ; 2.37)$ & $1.07(0.98 ; 1.17)$ \\
\hline Erythropoietin, ng/ml & ${ }^{* *} 4.5(4.2 ; 6.8)$ & ${ }^{*} 4.5 .(3.50 ; 5.75)$ & $23.5^{* *}(14.0 ; 29.5)$ & $3.9(3.3 ; 7.8)$ \\
\hline Ferritin, ng/ml & *56.5* $(48.0 ; 63.0)$ & $* 52 *(45 ; 78)$ & $43.5^{*}(23.0 ; 48.0)$ & $29(16 ; 50)$ \\
\hline
\end{tabular}

()*: $P<0.05$ - the significance of differences compared with the control group indicators; ()**: $P<0.01$ - the significance of differences compared with the control group indicators; ${ }^{*}(): P<0.05$ - the significance of differences compared with the comparison group indicators; **(): $P<0.01$ - the significance of differences compared with the comparison group indicators.

represented by 20 children with IDA without inflammatory manifestations. The control group included 20 conditionally healthy children. The studied groups of children were ageand sex-representative.

Blood serum hepcidin, erythropoietin, and ferritin levels were measured by enzyme-linked immunosorbent assay (ELISA) using commercial kits: Human Hepc (Hepcidin) ELISA Kit (Elabscience, USA), EPO (Erythropoietin) ELISA (Biomerica, Germany), Ferritin ELISA (ORGENTEC Diagnostika $\mathrm{GmbH}$, Germany).

The measuring serum total iron-binding capacity was carried out by a biochemical method on a Midray BS-200 analyzer using a commercial kit CORMAY IBC (PZ CORMAY S.A., Poland).

The coefficient of saturation of iron in transferrin was calculated by the formula:

Coefficient of saturation of iron in transferrin $=$

$$
=\frac{\mathrm{Fe}^{3+} \times 100}{\text { Total iron }- \text { binding capacity }},
$$

where $\mathrm{Fe}^{3+}$ - the serum iron content.

Statistical analysis of the data was performed using the statistical packages EXCEL and Statistica 13.0 (StatSoft Inc No. JPZ8041382130ARCN10-J). Normality of the data was checked using the Shapiro-Wilk test. We used the method of correlation analysis with the Spearman correlation coefficient calculation. Measurement data of a non-normal distribution and non-linear dependence were expressed as a median and quartile (Me (Q25; Q75)). To assess the differences in indicators, the nonparametric Mann - Whitney U-test was calculated as a nonparametric analogue of the Student criterion. Differences were considered at a significance level of $P<0.05$.

All procedures performed in studies involving human participants were in accordance with the Ethical Standards of the Institutional and National Research Committee and with the 1964 Declaration of Helsinki and its later amendments or comparable ethical standards. An informed consent was obtained from all individual participants included in the study. The full data set of children, their parents, and physician that support the findings of this study were not publicly available due to the restrictions of the ethics approval originally obtained.

\section{Results}

Taking into account the fact that pathogens mostly require iron for survival in the development of bacterial inflammatory process of the respiratory organs, we studied some indicators of iron metabolism in the groups of examined children. The results of the study are shown in Table 1.

As can be seen from the table, in children with bacterial respiratory diseases who developed $\mathrm{Al}$, there was an increased level of hepcidin, which was apparently linked to the protective and antimicrobial properties of this peptide [4]. The level of hepcidin in the studied groups depending on the pathogens was subsequently analyzed (Fig. 1).

The content of hepcidin in the blood serum in children of the main group, where the causative agent was Haemophilus influenzae, was $1.95(1.33 ; 2.40) \mathrm{ng} / \mathrm{ml}$, Streptococcus pneumoniae - $1.92(1.50 ; 2.37) \mathrm{ng} / \mathrm{ml}$, Klebsiella pneumoniae - $1.92(1.65 ; 2.10) \mathrm{ng} / \mathrm{ml}$, however, there was no statistically significant difference $(P>0.05)$ in the data obtained. The median hepcidin concentrations were 2 times $(P<0.05)$ significantly increased in children with $\mathrm{Al}$ as compared to the control group results. When comparing these data with the results obtained in the blood serum of children in the second subgroup and the comparison group, no statistically significant difference was found $(P>0.05)$. The revealed suppressive effect of IDA on hepcidin production may be due to requirements for increased iron utilization in the bone marrow for hemoglobin synthesis $[8,9]$.

At the same time, the hepcidin content in the blood serum of the main group children varied depending on the disease severity, which is clearly seen in the figure below (Fig. 2).

The serum level of hepcidin was increased in children of the first subgroup with the severe disease in comparison with the subgroup of children with the moderately severe disease $(2.40(2.24 ; 2.58)$ and $1.82(1.33 ; 2.26) \mathrm{ng} / \mathrm{ml}$ respectively, $P<0.05)$. In children of the second subgroup with severe disease, the hepcidin level was 2 times higher than in children with moderate severity of the disease $(1.93(1.91 ; 2.41) \mathrm{ng} / \mathrm{ml}$ and $0.92(0.87 ; 1.50)$ respectively, $\mathrm{P}<0.05)$.

Given the iron-regulatory role of hepcidin $[7,9]$, of particular interest was the analysis of iron metabolism in the examined children (Table 1).

A negative correlation was found between hepcidin and serum iron $(r=-0.74, P<0.05)$. In the first subgroup, low iron content was found compared with other groups. Thus, the median iron content in the control group was 1,6 times 


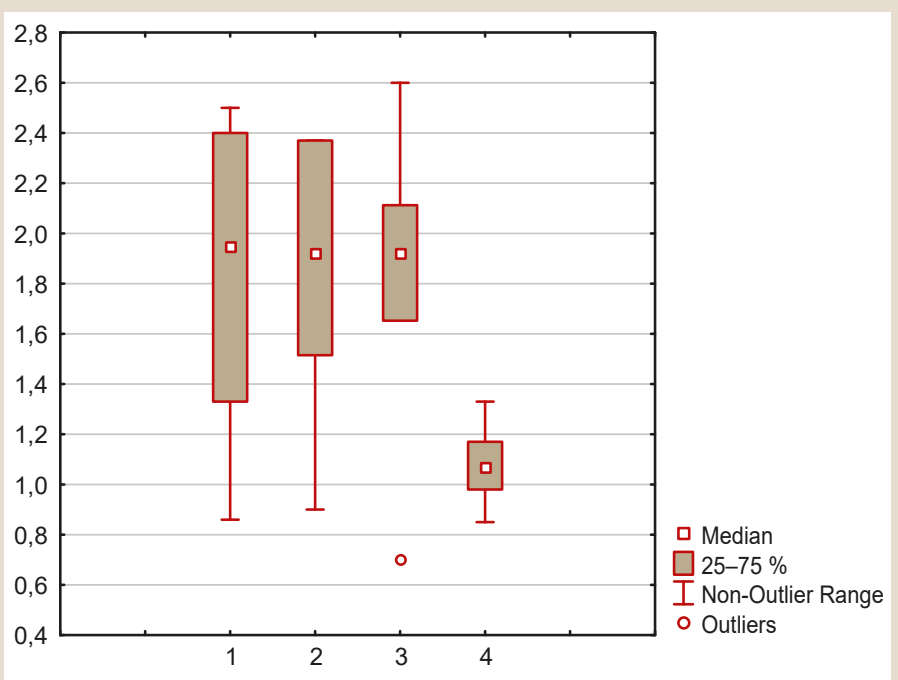

Fig. 1. The content of hepcidin in the blood serum depending on the pathogens.

1: Haemophilus influenzae; 2: Streptococcus pneumonia; 3: Klebsiella pneumonia; 4: the control group.

The subgroup 1, moderate severity

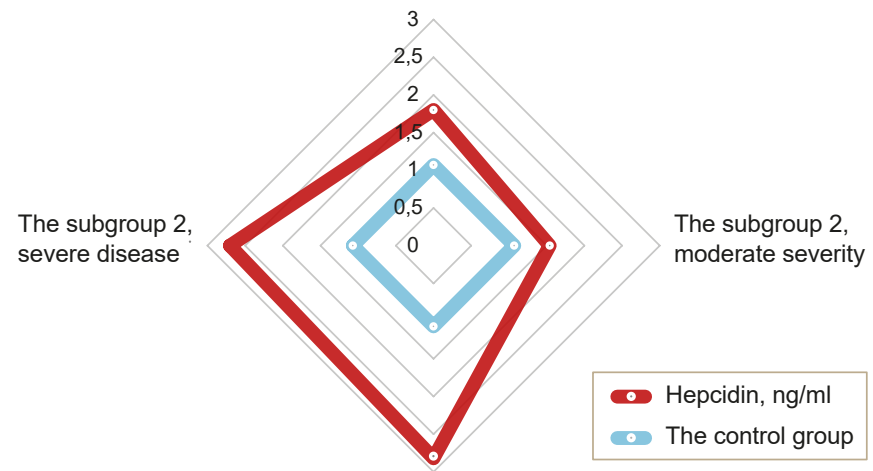

The subgroup 1, severe disease

Fig. 2. The content of hepcidin in the blood serum depending on the disease severity.

higher than that in the first subgroup $(P<0.05)$, and 1.5 times $(P<0.05)$ - in the comparison group. The level of iron in the second subgroup did not differ statistically significantly from that in the first subgroup, although an upward trend was evident $(P>0.05)$. However, we noted that in the second subgroup, similar to the first, the iron content was significantly lower than in the comparison and control groups $(P<0.05)$. The presence of an inverse correlation between hepcidin and serum iron, apparently, testified to the negative effect of hepcidin on the iron release from blood plasma stores, which is probably another manifestation and realization of anti-infection protection by hepcidin: this peptide restricts the availability of iron for bacterial growth [9]. In patients without anemia, hepcidin probably exhibits milder ferrostatic properties (less pronounced accumulation of serum ferritin and a decrease in iron levels), adequately adapts the amount of circulating iron to the needs of the organism, primarily to the needs of erythropoiesis, and thereby ensures the maintenance of normal hemoglobin concentrations. The absence of an indicative iron deficiency in children from the comparison group, we suggest, can be explained by the planned therapeutic prescription of iron-containing drugs.

We found a close direct correlation between the serum content of hepcidin and ferritin in the studied groups of children $(r=+0.93, P<0.01)$. A high level of ferritin was revealed in the main group without statistically significant difference between subgroups $(P>0.05)$. The median concentrations of ferritin in the main group were 2 times $(P<0.05)$ significantly higher than the data obtained in the control group. The difference in the results was not statistically significant in the comparison group $(P>0.05)$.

A negative correlation was found between hepcidin and coefficient of saturation of iron in transferring $(r=-0.59)$, which seemed logical, taking into account the level of serum iron in the studied groups. Thus, a low coefficient of saturation of iron in transferring in the second subgroup demonstrated a latent iron deficiency development. Its value was 1.5 times $(P<0.05)$ lower than in the comparison and control groups. The coefficient of saturation of iron in transferring did not differ statistically significantly $(P>0.05)$ between subgroups of the main group. It became apparent that inadequate delivery of the trace element to the bone marrow and iron-deficient erythropoiesis resulted from the decrease in serum iron saturation of transferrin. Thus, one of the mechanisms for the development of $\mathrm{Al}$ is the iron deficiency of redistributive origin [10].

When studying the data characterizing total iron-binding capacity, we revealed a statistically significant decrease in the level of blood serum total iron-binding ability only in a subgroup of children with $\mathrm{Al}(\mathrm{P}<0.05)$, in the group of children with IDA, only a downward tendency was noted $(P>0.05)$. At the same time, in the subgroup of children without $\mathrm{Al}$, we noted a significant increase blood serum total iron-binding ability $(P<0.05)$. Taking into account a statistically significant decrease $(P<0.05)$ relative to healthy children serum iron, transferrin saturation by iron and an increase in serum iron concentration at normal total iron-binding ability, the obtained data indicate the state of functional iron deficiency in patients. These changes in iron metabolism were significantly $(P<0.05)$ pronounced in patients with $\mathrm{Al}$.

When analyzing the data given in Table 1 , we noted the increased level of erythropoietin only in the group of children who were diagnosed with IDA. Its level was statistically significantly higher than the indices of both the main and control groups $(P<0.01)$. A significant increase in the serum content of erythropoietin in patients with IDA may be associated with hemic and tissue hypoxia [4]. There was no significant difference in the level of erythropoietin between the main and control group $(P>0.05)$.

\section{Discussion}

As a result of the study, it was demonstrated that Al in young children with acute bacterial diseases of the respiratory system was accompanied by the high level of hepcidin. The increase in hepcidin values did not depend on the etiology of the inflammatory process, which, to some extent, is consistent with the data of Nemeth E. (2006), who showed that hepcidin synthesis was induced exclusively by pro-inflammatory cytokines, in particular IL-6, independently of 
the infectious pathogen [7]. At the first stage of our study, a relative iron deficiency state was revealed, apparently due to the iron deposition, as evidenced by the twofold increase in the content of ferritin. Ferritin may not have been sufficiently low in the face of Al, as it reflects iron stores in the organism given the protective mechanism of deposition [10]. Pigeon et al. (2001) discovered that hepcidin mRNA expression in hepatocytes was increased in response to iron overload [11]. The iron deposition found as a result of the study was probably due to the need for its sequestration in response to invasion of bacterial agents, which are known to use iron for growth and action [12]. In the implementation of this mechanism, hepcidin has a direct coordinating effect. Increased hepcidin secretion in response to induction of the pro-inflammatory cytokines leads to a decrease in iron absorption by enterocytes, export from macrophages and a decrease in the plasma iron concentration with further development of Al [1]. The occurrence of a relative iron deficiency state is a protective mechanism aimed at localizing the inflammatory process and slowing down the growth and activity of bacterial agents $[13,14]$. The decrease in hepcidin values in IDA patients is consistent with the literature $[13,15]$, and is understandable in terms of hepcidin role in iron metabolism and an organism's attempt to replenish its reserves to ensure normal process of hemoglobin synthesis. These data are consistent with the opinion of Nemeth et al. [7] on the interaction between pro-inflammatory cytokines and hepcidin, which ultimately leads to a decrease in microbial growth. In conditions of $\mathrm{Al}$, a functional deficiency of iron occurs, the consequence of which is a decrease in hemoglobin synthesis. Hepcidin inhibits biologic activity of erythropoietin through hypoxia-inducible-factor 1 , erythroferrone, matriptase-2, growth differentiation factor-15, or platelet-derived growth factor-BB $[16,17]$. The importance of this pathogenetic link is to facilitate iron transit during erythropoiesis intensification. Despite the fact that the number of erythropoietin receptors seems to remain unchanged in patients with Al [4], our study has demonstrated a decreased effect of erythropoietin in children with Al. A comparative analysis of the serum erythropoietin content in children with IDA is indicative. In this condition, an increase in its content was logical due to the need to increase it in order to stimulate erythropoiesis. Activation of erythropoiesis increased the need for sufficiently active transportation of iron to the bone marrow for hemoglobin synthesis, which in turn, was ensured by optimizing the absorption of this trace element in the intestine or by mobilizing it from stores under the control of hepcidin level [7].

\section{Conclusions}

1. Hepcidin plays a significant pathogenetic role in the development of anemia of inflammation in young children due to the regulatory effect on the iron deposition.

2. The increase in hepcidin level in response to the development of a bacterial inflammatory process in the respiratory system in young children did not depend on the etiological factor of the disease.

Conflicts of interest: authors have no conflict of interest to declare. Конфлікт інтересів: віАсутній.
Funding

The study was conducted with financing from Zaporizhzhia State Medical University.

НаАійшла Ао редакції / Received: 24.02.2020

Після Аоопрацювання / Revised: 03.03.2020

Прийнято Ао Аруку / Accepted: 20.03.2020

Information about authors:

Lezhenko H. O., MD, PhD, DSc, Head of the Department of

Hospital Pediatrics, Zaporizhzhia State Medical University, Ukraine.

ORCID ID: 0000-0003-0851-4586

Pogribna A. O., MD, PhD Student of the Department of Hospital Pediatrics, Zaporizhzhia State Medical University, Ukraine.

Відомості про авторів:

Леженко Г. О., А-р меА. наук, професор, зав. каф. госпітальної педіатрії, Запорізький Аержавний медичний університет, україна.

Погрібна А. О., PhD аспірант каф. госпітальної педіатрії, Запорізький Аержавний медичний університет, Україна.

\section{Сведения об авторах:}

Леженко Г. А., А-р меА. наук, профессор, зав. каф. госпитальной пеАиатрии, Запорожский государственный медицинский университет, Украина.

Погребная A. A., PhD аспирант каф. госпитальной педиатрии,

Запорожский государственный меАицинский университет, Украина.

\section{References}

[1] Nemeth, E., Valore, E. V., Territo, M., Schiller, G., Lichtenstein, A., \& Ganz, T. (2003). Hepcidin, a putative mediator of anemia of inflammation, is a type Il acute-phase protein. Blood, 101(7), 2461-2463. https:// doi.org/10.1182/blood-2002-10-3235

[2] Babitt, J. L., Huang, F. W., Xia, Y., Sidis, Y., Andrews, N. C., \& Lin, H. Y. (2007). Modulation of bone morphogenetic protein signaling in vivo regulates systemic iron balance. The Journal of clinical investigation, 117(7), 1933-1939. https://doi.org/10.1172/JCl31342

[3] Babitt, J. L., Huang, F. W., Wrighting, D. M., Xia, Y., Sidis, Y., Samad, T. A., Campagna, J. A., Chung, R. T., Schneyer, A. L., Woolf, C. J., Andrews, N. C., \& Lin, H. Y. (2006). Bone morphogenetic protein signaling by hemojuvelin regulates hepcidin expression. Nature genetics, 38(5), 531-539. https://doi.org/10.1038/ng1777

[4] Weiss, G., Ganz, T., \& Goodnough, L. T. (2019). Anemia of inflammation. Blood, 133(1), 40-50. https://doi.org/10.1182/blood-2018-06-856500

[5] Nemeth, E., Tuttle, M. S., Powelson, J., Vaughn, M. B., Donovan, A., Ward, D. M., Ganz, T., \& Kaplan, J. (2004). Hepcidin regulates cellular iron efflux by binding to ferroportin and inducing its internalization. Science, 306(5704), 2090-2093. https://doi.org/10.1126/science.1104742

[6] Jelkmann, W. (2011). Regulation of erythropoietin production. The Journal of physiology, 589(Pt. 6), 1251-1258. https://doi.org/10.1113/ jphysiol.2010.195057

[7] Nemeth, E., \& Ganz, T. (2009). The Role of Hepcidin in Iron Metabolism. Acta Haematologica, 122(2-3), 78-86. https://doi. org/10.1159/000243791

[8] Yoon, D., Pastore, Y. D., Divoky, V., Liu, E., Mlodnicka, A. E., Rainey, K., Ponka, P., Semenza, G. L., Schumacher, A., \& Prchal, J. T. (2006). Hypoxia-inducible factor-1 deficiency results in dysregulated erythropoiesis signaling and iron homeostasis in mouse development. The Journal of biological chemistry, 281(35), 25703-25711. https://doi. org/10.1074/jbc.M602329200

[9] Ganz, T. (2003). Hepcidin, a key regulator of iron metabolism and mediator of anemia of inflammation. Blood, 102(3), 783-788. https:/l doi.org/10.1182/blood-2003-03-0672

[10] Kim, A., Fung, E., Parikh, S. G., Valore, E. V., Gabayan, V., Nemeth, E., \& Ganz, T. (2014). A mouse model of anemia of inflammation: complex pathogenesis with partial dependence on hepcidin. Blood, 123(8), 11291136. https://doi.org/10.1182/blood-2013-08-521419

[11] Pigeon, C., llyin, G., Courselaud, B., Leroyer, P., Turlin, B., Brissot, P., \& Loréal, O. (2001). A new mouse liver-specific gene, encoding a protein homologous to human antimicrobial peptide hepcidin, is overexpressed during iron overload. The Journal of biological chemistry, 276(11), 7811-7819. https://doi.org/10.1074/jbc.M008923200 
[12] Jurado, R. L. (1997). Iron, infections, and anemia of inflammation. Clinical infectious diseases, 25(4), 888-895. https://doi.org/10.1086/515549

[13] Brentnall, M., Rodriguez-Menocal, L., De Guevara, R. L., Cepero, E., \& Boise, L. H. (2013). Caspase-9, caspase- 3 and caspase-7 have distinct roles during intrinsic apoptosis. BMC cell biology, 14, Article 32. https:// doi.org/10.1186/1471-2121-14-32

[14] Rakba, N., Loyer, P., Gilot, D., Delcros, J. G., Glaise, D., Baret, P., Pierre, J. L., Brissot, P., \& Lescoat, G. (2000). Antiproliferative and apoptotic effects of O-Trensox, a new synthetic iron chelator, on differentiated human hepatoma cell lines. Carcinogenesis, 21(5), 943-951. https://doi.org/10.1093/carcin/21.5.943

[15] Ludwiczek, S., Aigner, E., Theurl, I., \& Weiss, G. (2003). Cytokine-mediated regulation of iron transport in human monocytic cells. Blood, 101(10), 4148-4154. https://doi.org/10.1182/blood-2002-08-2459

[16] Theurl, I., Aigner, E., Theurl, M., Nairz, M., Seifert, M., Schroll, A., Sonnweber, T., Eberwein, L., Witcher, D. R., Murphy, A. T., Wroblewski, V. J., Wurz, E., Datz, C., \& Weiss, G. (2009). Regulation of iron homeostasis in anemia of chronic disease and iron deficiency anemia: diagnostic and therapeutic implications. Blood, 113(21), 5277-5286. https://doi. org/10.1182/blood-2008-12-195651

[17] Atkinson, S. H., Rockett, K. A., Morgan, G., Bejon, P. A., Sirugo, G., O'Connell, M. A., Hanchard, N., Kwiatkowski, D. P., \& Prentice, A. M. (2008). Tumor necrosis factor SNP haplotypes are associated with iron deficiency anemia in West African children. Blood, 112(10), 4276-4283. https://doi.org/10.1182/blood-2008-06-162008 